University of Nebraska - Lincoln

DigitalCommons@University of Nebraska - Lincoln

\title{
Effect of Coal Combustion By-products on Phosphorus Runoff from a Coastal Plain Soil
}

\author{
Keisha N. Johnson \\ Pennsylvania State University, knj107@psu.edu \\ Arthur L. Allen \\ University of Maryland - Eastern Shore \\ Peter J. A. Kleinman \\ United States Department of Agriculture \\ Fawzy M. Hashem \\ University of Maryland - Eastern Shore \\ Andrew N. Sharpley \\ University of Arkansas \\ See next page for additional authors
}

Follow this and additional works at: https://digitalcommons.unl.edu/usdaarsfacpub

Part of the Agricultural Science Commons

Johnson, Keisha N.; Allen, Arthur L.; Kleinman, Peter J. A.; Hashem, Fawzy M.; Sharpley, Andrew N.; and Stout, William L., "Effect of Coal Combustion By-products on Phosphorus Runoff from a Coastal Plain Soil" (2011). Publications from USDA-ARS / UNL Faculty. 546.

https://digitalcommons.unl.edu/usdaarsfacpub/546

This Article is brought to you for free and open access by the U.S. Department of Agriculture: Agricultural Research Service, Lincoln, Nebraska at DigitalCommons@University of Nebraska - Lincoln. It has been accepted for inclusion in Publications from USDA-ARS / UNL Faculty by an authorized administrator of DigitalCommons@University of Nebraska - Lincoln. 


\section{Authors}

Keisha N. Johnson, Arthur L. Allen, Peter J. A. Kleinman, Fawzy M. Hashem, Andrew N. Sharpley, and William L. Stout 


\title{
Effect of Coal Combustion By-products on Phosphorus Runoff from a Coastal Plain Soil
}

\author{
KEISHA N. JOHNSON, ${ }^{1}$ ARTHUR L. ALLEN, ${ }^{2}$ \\ PETER J. A. KLEINMAN, ${ }^{3}$ FAWZY M. HASHEM, ${ }^{2}$ \\ ANDREW N. SHARPLEY, ${ }^{4}$ AND WILLIAM L. STOUT ${ }^{3}$ \\ ${ }^{1}$ Department of Crop and Soil Sciences, Agricultural Sciences and Industry \\ Building, Pennsylvania State University, University Park, Pennsylvania, USA \\ ${ }^{2}$ Nutrient Management Laboratory, Department of Agriculture, Food, and \\ Resource Sciences, University of Maryland Eastern Shore, Princess Anne, \\ Maryland, USA \\ ${ }^{3}$ U.S. Department of Agriculture, Agricultural Research Service, Pasture Systems \\ and Watershed Management Research Unit, University Park, Pennsylvania, USA \\ ${ }^{4}$ Crop and Environmental Sciences, University of Arkansas, Fayetteville, \\ Arkansas, USA
}

\begin{abstract}
Coal combustion by-products can lower soil phosphorus $(P)$ solubility, but few studies have assessed their effect on runoff $P$. A soil with elevated $P$ content was amended with fluidized bed combustion ash, flue gas desulfurization gypsum, and anthracite refuse ash at rates of 0-40 $\mathrm{g} \mathrm{kg}^{-1}$ soil, and runoff from small plots was monitored over 3 years. In the first year, by-products lowered dissolved P in runoff by up to $47 \%$ below the untreated control; however, effects did not persist into the remaining years of the study. Total P losses were not significantly affected by coal combustion by-products, likely because of elevated particulate P losses. Water-extractable P was up to $40 \%$ less in treated soils than in untreated soils across the 3 years. Results demonstrate that although coal combustion by-products readily lower P solubility in soils, their impact on $P$ losses in runoff can be undermined by erosional processes.
\end{abstract}

Keywords Fly ash, phosphorus, water quality

\section{Introduction}

Effects of phosphorus (P) runoff from agricultural soils on water quality is a widespread concern because of the role of $\mathrm{P}$ in accelerating the eutrophication of freshwater systems (Carpenter et al. 1998). Long-term application of manure to agricultural soils can enrich $\mathrm{P}$ pools that are readily available to runoff (Graetz and Nair 1995; Ebeling et al. 2002). Many studies document strong correlations between soil-test $\mathrm{P}$ and dissolved $\mathrm{P}$ concentrations in runoff (Pote et al. 1999). On the Delmarva Peninsula (Delaware, Maryland, and Virginia), particularly in areas of intensive poultry production, losses of $\mathrm{P}$ in runoff are of concern

Received 5 August 2009; accepted 13 September 2010.

This paper is dedicated to the memory of William (Bill) Stout, mentor, friend, and passionate conservationist.

Address correspondence to K. N. Johnson, Crop and Soil Sciences, Agricultural Sciences and Industry Building, Pennsylvania State University, University Park, PA. E-mail: knj107@ psu.edu 
given the mounting soil P levels and the immediate proximity to the Chesapeake Bay (Sims and Kleinman 2005). This important estuary and its tributaries are prone to both nitrogen (N)- and P-induced eutrophication (Boesch, Brinsfield, and Magnien 2001).

Although many best-management practices are used to control $\mathrm{P}$ in runoff from agricultural soils, most are geared toward controlling particulate $\mathrm{P}$ transfers arising from soil erosion (Sims and Kleinman 2005). Few options exist to lower dissolved P losses in runoff from soils that are already high in $\mathrm{P}$ (Sharpley 2003). One area of growing interest has been the use of amendments that decrease P availability to runoff water (Novak and Watts 2005). A variety of studies show that treating poultry litter with alum can decrease waterextractable $\mathrm{P}$ (WEP) in litter. When litter is then applied to land, dissolved P losses in runoff are lowered (Moore, Daniel, and Edwards 2000; Smith et al. 2004). Other amendments that have been evaluated in early laboratory studies are P-sorbing materials. For instance, Codling, Chaney, and Mulichi (2000) observed reductions in WEP after incubating soils and poultry litter in pots with municipal by-products. Similarly, Peters and Basta (1996) observed reductions in WEP from soils amended with aluminum $(\mathrm{Al})$-enriched solids from water treatment plants and iron $(\mathrm{Fe})$-enriched bauxite mixed with calcium $(\mathrm{Ca})$-enriched gypsum. Although such studies effectively demonstrate the potential to lower P solubility in soils, they do not directly measure $\mathrm{P}$ loss in runoff and thus provide limited information on other factors that help determine their suitability as an agricultural amendment. To be an appropriate agricultural amendment, a P-sorbing material should be nondeleterious to crop production and possess favorable agronomic qualities. Most important, an amendment must not create hazards with regard to soil, water, and crops and should be economically feasible.

One source of materials that has been considered for use in agriculture is the electric industry's coal combustion by-products (CCPs). A total of approximately 2 million tons of coal ash (fly and bottom ash) is generated annually from Maryland plants (Maryland Department of the Environment 2009). The most abundant CCP is coal ash (Punshon, Adriano, and Weber 2001), a mix of amorphous, ferro-alumino silicate minerals (Ghodrati, Sims, and Vasilas 1995; Adriano et al. 1980), along with a diverse array of constituents that include arsenic (As), boron (B), Ca, molybdenum (Mo), sulfur (S), and selenium (Se) (Page et al. 1979; Kost, Elseewi, and Straughan 2005). In addition to coal ash, CCPs include materials from the flue gas desulfurization (FGD) process where lime is used to remove $S$ from gaseous emissions during combustion of high S coal (Punshon, Adriano, and Weber 2001). These materials are alkaline and contain calcite, dolomite, calcium oxide, calcium hydroxide, gypsum, calcium sulfite, magnesium sulfate, magnesium oxide, and fly ash (Crews and Dick 1998). Generally, FGD by-products do not possess an abundance of trace elements (Punshon, Adriano, and Weber 2001).

Considerable precedent exists for using CCPs as soil amendments in agriculture. For example, studies have shown the potential for using CCPs amendments on agricultural soils to lower subsoil acidity (O'Reilly and Sims 1995; Sims, Vasilas, and Ghodrati 1995), improve soil texture and water-holding capacity by increasing aeration (Sell et al. 1989), improve soil infiltration properties (Kukier, Sumner, and Miller 2001), reduce bulk density (Chang et al. 1977), enhance soil fertility (Carlson and Adriano 1993), and improve crop yields (Stout and Priddy 1996). Simultaneously, concerns over the use of CCPs in agriculture have also been raised. Studies have shown that CCPs can potentially cause phytotoxicity from soluble elements, especially trace elements that adversely affect crop, soil, and possibly water quality (Adriano et al 1980; Sims, Vasilas, and Ghodrati 1995; Matsi and Keramidas 2001). Careful selection of CCPs and application at appropriate rates are therefore required if these materials are to be recommended for use in agriculture (Korcak 1995). 
Others have also evaluated the use of CCPs as a potential P-sorbing material to remediate high-P soils in laboratory studies. For instance, Stout, Sharpley, and Pionke (1998) reported fluidized bed coal ash (FBC) and FGD by-product incubation $\left(10 \mathrm{~g} \mathrm{~kg}^{-1}\right)$ with soil reduced WEP by $60 \%$ and 50\% respectively. Elsewhere, Callahan et al. (2002) found that incubation with FBC and FGD $\left(40 \mathrm{~g} \mathrm{~kg}^{-1}\right)$ reduced WEP by at least $50 \%$. In one of the few field studies evaluating CCPs as P-sorbing amendments, Stout, Sharpley, and Landa (2000) reported that FBC and FGD reduced dissolved P in runoff by $20 \%$ and $43 \%$, respectively, when incorporated in the surface $5 \mathrm{~cm}$ of an acidic $(\mathrm{pH}=6.0)$ soil at $20 \mathrm{~g} \mathrm{~kg}^{-1}$.

The mechanisms by which CCPs decrease P solubility are not fully understood given their heterogeneous nature and interaction with soil particles. In the case of FBC, high concentrations of $\mathrm{Ca}$ are thought to promote the formation of $\mathrm{Ca}$ phosphates, which are stable in neutral and alkaline soils but less so in acidic soils (Lindsay 1979). As a result of being a comparatively good liming agent (Callahan et al. 2002), application of FBC to moderately acidic soil can increase soil $\mathrm{pH}$ sufficiently to cause possible formation of $\mathrm{Ca}$ phosphates. When FBC is used in acidic soils, applied Ca likely displaces exchangeable Fe and $\mathrm{Al}$ via mass action (Brady and Weil 1996), increasing Fe and $\mathrm{Al}$ in the soil solution and promoting the formation of $\mathrm{Fe}$ and $\mathrm{Al}$ phosphates, which are relatively stable in acidic soils (Lindsay 1979). This mechanism has also been hypothesized for increased $\mathrm{P}$ sorption in FGD-amended soils (Stout, Sharpley, and Landa 2000). For anthracite refuse ash (ARA), mechanisms of $\mathrm{P}$ sorption are by both $\mathrm{Fe}$ and $\mathrm{Al}$, either in the form of electrolytes or hydrous minerals (Callahan et al. 2002).

This study evaluated the potential for using CCPs in conventional corn production on an acidic soil with Mehlich $3 \mathrm{P}$ concentrations well in excess of crop requirements (338 mg kg-1). Specific objectives of this study were to determine the effectiveness of CCPs in reducing $\mathrm{P}$ losses in runoff as a function of CCP type, application rate, and time as well as to assess the effect of CCPs on soil properties tied to P cycling.

\section{Materials and Methods}

\section{Study Site}

This study was conducted on a 2-ha field within the University of Maryland Eastern Shore (UMES) research farm ( $38^{\circ} 12^{\prime} 22^{\prime \prime} \mathrm{N}$ and $75^{\circ} 40^{\prime} 35^{\prime \prime} \mathrm{W}$ ) in Princess Anne, Maryland. The farm, formerly a commercial poultry operation with a 30 -year history of intensive poultry litter application, was purchased by UMES in 1996. Soils grade from the poorly drained Othello series (fine-silty, mixed, active, mesic Typic Endoaquult) to the welldrained Matapeake series (fine-silty, mixed, semi-active, mesic Typic Hapludult). Soils have an average slope of $3 \%$ and high concentrations of P (Mehlich $3 \mathrm{P}>300 \mathrm{mg} \mathrm{kg}^{-1}$ ) due to a long history of receiving poultry litter at rates often exceeding annual crop removal (Kleinman et al. 2007). Soils were cropped in corn-wheat-soybean rotation. Temperature and precipitation measurements, recorded on a continual (5-min) basis over the 3-year study period, were $115 \mathrm{~cm} \mathrm{yr}^{-1}$ (excluding snowfall) and $13{ }^{\circ} \mathrm{C}$ (monthly averages ranged from $4{ }^{\circ} \mathrm{C}$ to $25^{\circ} \mathrm{C}$ ).

\section{Surface Runoff Experiment}

Forty-eight surface runoff plots $(60 \times 120 \mathrm{~cm})$ were established within the UMES research farm by a modified design of Stout, Sharpley, and Landa (2000). Runoff plots consisted of painted steel borders $(15 \mathrm{~cm}$ high) pushed $10 \mathrm{~cm}$ into the soil with a covered gutter located 
Table 1

Select properties of coal combustion byproducts used in runoff study

\begin{tabular}{lccc}
\hline & \multicolumn{3}{c}{ Coal combustion byproduct } \\
\cline { 2 - 4 } Property & ARA & FBC & FGD \\
\hline Relative P sorption potential & & & \\
$\quad$ P sorbed (mg kg & \\
Solution P $\left(\mathrm{mg} \mathrm{L}^{-1}\right)$ & 999 & 998 & 109 \\
$\mathrm{pH}(1: 1$ water) & 0.24 & 1.67 & 890 \\
Solids $(\%)$ & 10.7 & 12.8 & 7.8 \\
$2 \mathrm{MCl} \mathrm{extractable}$ & 97.5 & 99.2 & 82 \\
$\mathrm{Al}\left(\mathrm{mg} \mathrm{kg}^{-1}\right)$ & & & \\
$\mathrm{Ca}\left(\mathrm{mg} \mathrm{kg}^{-1}\right)$ & $\mathrm{nd}$ & $\mathrm{nd}$ & $\mathrm{nd}$ \\
$\mathrm{Fe}\left(\mathrm{mg} \mathrm{kg}^{-1}\right)$ & 1108 & 2728 & 2189 \\
$\mathrm{P}\left(\mathrm{mg} \mathrm{kg}^{-1}\right)$ & $\mathrm{nd}$ & $\mathrm{nd}$ & $\mathrm{nd}$ \\
$\mathrm{S}\left(\mathrm{mg} \mathrm{kg}^{-1}\right)$ & $\mathrm{nd}$ & $\mathrm{nd}$ & $\mathrm{nd}$ \\
Elemental content, \% of total & 853 & 1766 & 1863 \\
$\mathrm{Al}$ & & & \\
$\mathrm{Ca}$ & 3.5 & 2.1 & 0.01 \\
$\mathrm{Fe}$ & 3.6 & 14.8 & 6.2 \\
$\mathrm{P}$ & 1.3 & 2.2 & 0.03 \\
$\mathrm{~S}$ & 0.02 & 0.04 & 0.02 \\
\hline
\end{tabular}

${ }^{\dagger} \mathrm{KCl}=$ extractable and total elemental concentrations are on a dry weight basis

$\stackrel{+}{+}$ nd = non-detectable (concentration in extract below detection limit of ICP-AES)

at the lower front end of each plot. An 8-L collection bottle was housed inside of a buried 20-L bucket (with top lid) to collect runoff.

Three by-products (ARA, FBC, FGD) obtained from power plants in Pennsylvania (Table 1) were applied to plots in a randomized complete block design with four replications. Generally, but not in all cases, these materials contain high-quality gypsum $\left(\mathrm{CaSO}_{4}\right)$ and low levels of trace elements. Coal combustion by-products were applied at four rates $\left(0,1020\right.$, and $40 \mathrm{~g} \mathrm{CCP} \mathrm{kg}^{-1}$ soil) and incorporated into the upper $5 \mathrm{~cm}$ of soil in March 2000 (the first year of study only). Rates were selected to give a range of expected WEP concentrations in the amended soils based upon a laboratory study of Stout, Sharpley, and Landa (2000).

Runoff and Soil Sampling. Runoff was monitored on a storm-event basis from March 2000 to September 2002. When runoff was present, the total volume was recorded and a $250-\mathrm{mL}$ subsample was retained in a plastic bottle that was stored at $4{ }^{\circ} \mathrm{C}$ within $1 \mathrm{~h}$ of collection. Samples were collected, filtered $(0.45-\mu \mathrm{m}$ filter $)$, and analyzed immediately, in some cases within 1 week of filtering. The first rain event occurred within 2 to 3 weeks after CCPs were applied.

Six soil cores (2-cm diameter) were obtained from the upper $15 \mathrm{~cm}$ within each runoff field plot on three occasions during the study: October 2000 (7 months after 
CCP application); April 2002 (25 months after CCP application); and September 2002 (30 months after CCP application). All cores from a single plot were thoroughly mixed, and a 50-g composite sample was obtained for analysis. Soil was air dried $\left(25^{\circ} \mathrm{C}\right)$ and sieved (2-mm) prior to laboratory analysis.

\section{Laboratory Analysis}

Coal Combustion By-products. All CCP samples were run in triplicate. Readily desorbable $\mathrm{Al}, \mathrm{Ca}, \mathrm{Fe}$, and $\mathrm{P}$ were determined by shaking $\mathrm{CCPs}$ with $2 \mathrm{M}$ potassium chloride $(\mathrm{KCl})$ ( solid/solution $=1: 5$ ) for $30 \mathrm{~min}$. Following filtration (Whatman No. 1), the supernatant was analyzed by inductively coupled plasma-atomic emission spectrometry (ICP-AES). Total elemental analysis of CCPs was determined by EPA method 3050/3051 (U.S. Environmental Protection Agency 1986), with digests analyzed by ICP-AES for Al, Ca, $\mathrm{Fe}, \mathrm{P}$, and S. Single-point sorption experiments were conducted to evaluate the relative P-sorption potential of CCPs prior to their addition to soil. A solution containing 1000 mg P L ${ }^{-1}$ [as monopotassium phosphate $\left(\mathrm{KH}_{2} \mathrm{PO}_{4}\right)$ in $0.01 \mathrm{M}$ calcium chloride $\left(\mathrm{CaCl}_{2}\right)$ ] was shaken with each of the CCPs for $24 \mathrm{~h}$ (solid/solution =1:25). The mixture was filtered (Whatman No. 1) and the supernatant analyzed for P by modified colorimetric method of Murphy and Riley (1962), at a wavelength of $712 \mathrm{~nm}$. The amount of $\mathrm{P}$ sorbed ( $\left.\mathrm{mg} \mathrm{P} \mathrm{kg}^{-1}\right)$ and equilibrium solution concentration $\left(\mathrm{mg} \mathrm{L}^{-1}\right)$ were used as indicators of relative P-sorption potential. The $\mathrm{pH}$ of CCPs was determined in a water (solid/ solution $=1: 1$ ).

Runoff Water. Dissolved P was determined on filtered $(0.45-\mu \mathrm{m})$ water samples by colorimetry. Total $\mathrm{P}$ was determined on unfiltered samples by a semi-micro-Kjeldahl digestion procedure (Bremner 1996), with P in digests determined by colorimetry. Total solids were determined by gravimetric analysis, after evaporating $200 \mathrm{~mL}$ of unfiltered runoff water at $80{ }^{\circ} \mathrm{C}$.

Soils. Soil samples were analyzed for Mehlich 3-extractable $\mathrm{P}, \mathrm{K}, \mathrm{Ca}$, and $\mathrm{Mg}$ by shaking soil and Mehlich 3 solution [0.2 N acetic acid $\left(\mathrm{CH}_{3} \mathrm{COOH}\right), 0.25 \mathrm{~N}$ ammonium nitrate $\left(\mathrm{NH}_{4} \mathrm{NO}_{3}\right), 0.015 \mathrm{~N}$ ammonium fluoride $\left(\mathrm{NH}_{4} \mathrm{~F}\right), 0.013 \mathrm{~N}$ nitric acid $\left(\mathrm{HNO}_{3}\right)$, and 0.001 $N$ ethylenediaminetetraacetic acid (EDTA)] for $5 \mathrm{~min}$ (soil/solution $=1: 10$ ), followed by filtration (Whatman No. 1) and analysis of the supernatant by ICP-AES (Mehlich 1984). Water-extractable soil $\mathrm{P}$ was measured by shaking soil and deionized water (soil/solution $=1: 10$ ) for $1 \mathrm{~h}$, followed by filtration (Whatman 1 ) and colorimetric determination of P (Murphy and Riley 1962). Soil pH was determined in distilled water (soil/ solution $=1: 1)$.

\section{Statistical Analysis}

Statistical analyses were conducted using SAS, version 8 (SAS Institute Inc. 1999). Data were analyzed by SAS's PROC Univariate to confirm assumption of normality and equal variance distribution. Runoff $\mathrm{P}$ and sediment data were analyzed on an annual basis, with concentration data $\left(\mathrm{mg} \mathrm{L}^{-1}\right)$ for individual runoff events weighted relative to total annual flow volumes. All data were analyzed by the general linear model, using Duncan's test for pairwise comparison of means. Differences discussed in the text were significant at $\alpha \leq 0.05$. 


\section{Results and Discussion}

\section{Properties of Coal Combustion By-products}

The CCPs (FGD, FBC, and ARA) used in this study exhibited key differences with respect to properties salient to soil $\mathrm{P}$ chemistry (Table 1). Single-point sorption experiments revealed substantial differences in relative $\mathrm{P}$ sorption potential of the CCPs prior to their application to soil. Both ARA and FBC sorbed nearly all of the P from solution, while FGD sorbed relatively little. Equilibrium solution $\mathrm{P}$ concentrations followed the trend of FGD $>>$ FBC $>$ ARA, implying that FGD is considerably less effective at maintaining low solution-P concentrations than either FBC or ARA. It is important to reiterate that these sorption properties point to inherent differences in CCPs prior to their addition to soil. Once applied to soils, interactions between CCPs and soil will likely modify their relative sorption potentials. Thus, it appears as though these types of sorption studies are probably not good indicators of the potential impact of effects of CCPs treatments on P in surface runoff.

Callahan et al. (2002) found FGD to be more effective in promoting P sorption than ARA when mixed with acidic soils. All CCPs had low concentrations of total P and nondetectable concentrations of $2 \mathrm{M} \mathrm{KCl}$ extractable $\mathrm{P}$, suggesting that their addition to soil should not substantially increase either total or readily desorbable P. Relative differences in $\mathrm{pH}$ of the three CCPs used (Table 1) were similar to differences in $\mathrm{CaCO}_{3}$ equivalency values reported by Callahan et al. (2002), for $\mathrm{FBC}\left(\mathrm{CaCO}_{3}\right.$ equivalent $\left.=57 \%\right)$, $\mathrm{ARA}\left(\mathrm{CaCO}_{3}\right.$ equivalent $=21 \%)$, and $\mathrm{FGD}\left(\mathrm{CaCO}_{3}\right.$ equivalent $\left.=16 \%\right)$.

The CCPs used in this study contained varying amounts of $\mathrm{Ca}, \mathrm{Fe}$, and $\mathrm{Al}$, with $\mathrm{Al}$ being the smallest for FGD (Table 1), all of which are known to decrease the solubility of $\mathrm{P}$ under certain environmental conditions. Fluidized bed combustion coal ash $(\mathrm{pH}=12.8)$ contained a large concentration of total $\mathrm{Ca}(14.8 \%)$ but a relatively small concentration of $2 \mathrm{M} \mathrm{KCl}$-extractable $\mathrm{Ca}(0.3 \%)$. Compared with $\mathrm{Ca}$, lesser concentrations of total $\mathrm{Fe}$ and $\mathrm{Al}$ were found in $\mathrm{FBC}$, and neither $\mathrm{Fe}$ nor $\mathrm{Al}$ was detectable in $2 \mathrm{M} \mathrm{KCl}$ extracts (Table 1). Elsewhere, Callahan et al. (2002) reported that Ca compounds serve as the primary control on $\mathrm{P}$ solubility in FBC. Anthracite refuse ash $(\mathrm{pH}=10.7)$ contained a lesser concentration of total $\mathrm{Ca}(3.6 \%)$, with approximately $0.1 \%$ extractable by $2 \mathrm{M} \mathrm{KCl}$. As with $\mathrm{FBC}$, total $\mathrm{Fe}$ and $\mathrm{Al}$ were found in lesser concentrations, with none detectable in $2 \mathrm{M} \mathrm{KCl}$ extracts. These findings appear to contrast with those of Callahan et al. (2002), who identified Fe as the dominant control of $\mathrm{P}$ solubility in ARA and suggest instead that Ca may serve as a key control of P solubility when ARA is applied to soil. Analysis of FGD, which is purported in most cases, but not all, to consist primarily of gypsum, revealed a low concentration of total $\mathrm{Ca}(6.2 \%)$ and total S (5.1\%) content, with $2 \mathrm{M} \mathrm{KCl-extractable} \mathrm{Ca}$ and $\mathrm{S}$ concentrations near $0.2 \%$. These findings suggest a relatively low gypsum content in the FGD used in the current study, confirming the finding of Kost et al. (2005) that FGD represents a heterogeneous class of materials.

\section{Effect of Coal Combustion By-products on P in Runoff and Soil}

Runoff. Rainfall during the study period (2000-2002) was 15-56\% less than the long-term average (Table 2). Even so, a total of 32 runoff events were sampled over the course of the study, yielded 14, 11, and 7 events, respectively, in 2000, 2001, and 2002. Concentrations of $\mathrm{P}$ in runoff from the unamended control treatments were high (dissolved $\mathrm{P}$ averaged .93-2.86 $\mathrm{mg} \mathrm{L}^{-1}$, total $\mathrm{P}$ averaged 2.97-6.91 $\mathrm{mg} \mathrm{L}^{-1}$ ), as were related losses (dissolved $\mathrm{P}$ averaged 2.71-11.14 $\mathrm{kg} \mathrm{ha}^{-1}$; total $\mathrm{P}$ averaged 11.97-17. $66 \mathrm{~kg} \mathrm{ha}^{-1}$ ). 
Table 2

Mean annual runoff properties from field plots treated with coal combustion byproducts

\begin{tabular}{|c|c|c|c|c|c|c|c|}
\hline \multirow[b]{2}{*}{$\mathrm{CCP}$ treatment } & \multirow{2}{*}{$\begin{array}{c}\mathrm{CCP} \\
\text { application } \\
\text { rate }\end{array}$} & \multirow[b]{2}{*}{$\mathrm{N}$} & \multirow{2}{*}{$\begin{array}{c}\text { Runoff } \\
\text { depth }\end{array}$} & \multicolumn{2}{|c|}{$\begin{array}{c}\text { Runoff P } \\
\text { concentration }\end{array}$} & \multicolumn{2}{|c|}{ Runoff P loss } \\
\hline & & & & Dissolved & Total & Dissolved & Total \\
\hline & $\mathrm{g} \mathrm{kg}^{-1}$ & & $\mathrm{~cm}$ & \multicolumn{2}{|c|}{$\mathrm{mg} \mathrm{L}^{-1}$} & \multicolumn{2}{|c|}{$\mathrm{kg} \mathrm{ha}^{-1}$} \\
\hline & \multicolumn{7}{|c|}{$2000($ total rainfall $=98 \mathrm{~cm})$} \\
\hline $\begin{array}{l}\text { Unamended } \\
\text { control }\end{array}$ & 0 & 12 & $0.43 \mathrm{a}^{\dagger}$ & $1.13 \mathrm{a}$ & $4.86 \mathrm{a}$ & $3.49 \mathrm{a}$ & $15.81 \mathrm{a}$ \\
\hline \multirow[t]{3}{*}{ ARA amended } & 10 & 4 & $0.45 \mathrm{a}$ & $0.94 \mathrm{ab}$ & $4.37 \mathrm{a}$ & $2.99 \mathrm{ab}$ & $14.00 \mathrm{a}$ \\
\hline & 20 & 4 & $0.44 \mathrm{a}$ & $0.65 b c$ & $4.34 \mathrm{a}$ & $2.05 b c$ & $13.97 \mathrm{a}$ \\
\hline & 40 & 4 & $0.4 \mathrm{a}$ & $0.64 \mathrm{bc}$ & $4.45 \mathrm{a}$ & $1.88 \mathrm{c}$ & $13.07 \mathrm{a}$ \\
\hline \multirow[t]{3}{*}{ FBC amended } & 10 & 4 & $0.41 \mathrm{a}$ & $0.74 \mathrm{~b}$ & $4.52 \mathrm{a}$ & $2.09 \mathrm{bc}$ & $13.18 \mathrm{a}$ \\
\hline & 20 & 4 & $0.44 \mathrm{a}$ & $0.63 \mathrm{bc}$ & $4.73 \mathrm{a}$ & $1.99 \mathrm{bc}$ & $15.32 \mathrm{a}$ \\
\hline & 40 & 4 & $0.43 \mathrm{a}$ & $0.39 \mathrm{c}$ & $3.99 \mathrm{a}$ & $1.19 \mathrm{c}$ & $12.45 \mathrm{a}$ \\
\hline \multirow[t]{4}{*}{ FGD amended } & 10 & 4 & $0.42 \mathrm{a}$ & $0.70 \mathrm{bc}$ & $4.11 \mathrm{a}$ & $2.13 \mathrm{bc}$ & $12.82 \mathrm{a}$ \\
\hline & 20 & 4 & $0.46 \mathrm{a}$ & $0.63 \mathrm{bc}$ & $4.99 \mathrm{a}$ & $2.07 \mathrm{bc}$ & $16.61 \mathrm{a}$ \\
\hline & 40 & 4 & $0.29 \mathrm{~b}$ & $0.59 \mathrm{bc}$ & $3.44 \mathrm{a}$ & $1.54 \mathrm{c}$ & $8.12 \mathrm{a}$ \\
\hline & \multicolumn{7}{|c|}{$2001($ total rainfall $=51 \mathrm{~cm})$} \\
\hline $\begin{array}{l}\text { Unamended } \\
\text { control }\end{array}$ & 0 & 12 & $0.39 \mathrm{a}$ & $0.93 \mathrm{abc}$ & $6.91 \mathrm{a}$ & $2.71 \mathrm{ab}$ & $17.66 \mathrm{a}$ \\
\hline \multirow[t]{3}{*}{ ARA amended } & 10 & 4 & $0.38 \mathrm{a}$ & $0.95 \mathrm{abc}$ & $5.63 \mathrm{a}$ & $2.65 \mathrm{ab}$ & $15.15 \mathrm{a}$ \\
\hline & 20 & 4 & $0.32 \mathrm{a}$ & $0.56 \mathrm{bc}$ & $6.60 \mathrm{a}$ & $1.27 \mathrm{~b}$ & $15.57 \mathrm{a}$ \\
\hline & 40 & 4 & $0.31 \mathrm{a}$ & $0.49 \mathrm{~b}$ & $8.16 \mathrm{a}$ & $1.10 \mathrm{~b}$ & $17.69 \mathrm{a}$ \\
\hline \multirow[t]{3}{*}{ FBC amended } & 10 & 4 & $0.37 \mathrm{a}$ & $1.10 \mathrm{a}$ & $7.66 \mathrm{a}$ & $3.25 \mathrm{a}$ & $20.19 a$ \\
\hline & 20 & 4 & $0.34 \mathrm{a}$ & $0.64 \mathrm{abc}$ & $5.29 \mathrm{a}$ & $1.56 \mathrm{ab}$ & $12.67 \mathrm{a}$ \\
\hline & 40 & 4 & $0.40 \mathrm{a}$ & $0.52 \mathrm{bc}$ & $6.21 \mathrm{a}$ & $1.53 \mathrm{ab}$ & $17.63 \mathrm{a}$ \\
\hline \multirow[t]{3}{*}{ FGD amended } & 10 & 4 & $0.33 \mathrm{a}$ & $0.75 \mathrm{abc}$ & $6.62 \mathrm{a}$ & $1.81 \mathrm{ab}$ & $14.63 \mathrm{a}$ \\
\hline & 20 & 4 & $0.37 \mathrm{a}$ & $0.99 \mathrm{ab}$ & $6.14 \mathrm{a}$ & $2.77 \mathrm{ab}$ & $16.67 \mathrm{a}$ \\
\hline & 40 & 4 & $0.40 \mathrm{a}$ & $0.87 \mathrm{abc}$ & $6.61 \mathrm{a}$ & $2.51 \mathrm{ab}$ & $18.22 \mathrm{a}$ \\
\hline & \multicolumn{7}{|c|}{$2002($ total rainfall $=70 \mathrm{~cm})$} \\
\hline $\begin{array}{l}\text { Unamended } \\
\text { control }\end{array}$ & 0 & 12 & $0.55 \mathrm{ab}$ & $2.86 \mathrm{a}$ & $2.97 \mathrm{a}$ & $11.14 \mathrm{a}$ & $11.97 \mathrm{a}$ \\
\hline \multirow[t]{3}{*}{ ARA amended } & 10 & 4 & $0.53 \mathrm{bc}$ & $2.61 \mathrm{a}$ & $3.40 \mathrm{a}$ & $10.12 \mathrm{a}$ & $12.89 \mathrm{a}$ \\
\hline & 20 & 4 & $0.56 \mathrm{a}$ & $2.25 \mathrm{a}$ & $2.91 \mathrm{a}$ & $9.09 \mathrm{a}$ & $11.77 \mathrm{a}$ \\
\hline & 40 & 4 & $0.50 \mathrm{bc}$ & $1.95 \mathrm{a}$ & $2.91 \mathrm{a}$ & $6.82 \mathrm{a}$ & $10.78 \mathrm{a}$ \\
\hline \multirow[t]{3}{*}{ FBC amended } & 10 & 4 & $0.51 \mathrm{bc}$ & $2.74 \mathrm{a}$ & $3.00 \mathrm{a}$ & $10.05 \mathrm{a}$ & $11.03 \mathrm{a}$ \\
\hline & 20 & 4 & $0.51 b c$ & $2.35 \mathrm{a}$ & $2.65 \mathrm{a}$ & $8.67 \mathrm{a}$ & $9.76 \mathrm{a}$ \\
\hline & 40 & 4 & $0.56 \mathrm{a}$ & $2.02 \mathrm{a}$ & $3.38 \mathrm{a}$ & $8.06 \mathrm{a}$ & $13.53 \mathrm{a}$ \\
\hline \multirow[t]{3}{*}{ FGD amended } & 10 & 4 & $0.53 \mathrm{abc}$ & $2.49 \mathrm{a}$ & $3.24 \mathrm{a}$ & $8.98 \mathrm{a}$ & $12.15 \mathrm{a}$ \\
\hline & 20 & 4 & $0.46 \mathrm{bc}$ & $2.71 \mathrm{a}$ & $2.37 \mathrm{a}$ & $8.69 \mathrm{a}$ & $7.55 \mathrm{a}$ \\
\hline & 40 & 4 & $0.45 \mathrm{c}$ & $2.65 \mathrm{a}$ & $2.35 \mathrm{a}$ & $8.47 \mathrm{a}$ & $7.98 \mathrm{a}$ \\
\hline
\end{tabular}

${ }^{\dagger}$ Letters represent Duncan's mean groupings $(\alpha=0.05)$ of different runoff properties for CCP and the control treatments, and are meant for comparisons within a single year only $(2000,2001$ or 2002). 
The effects of CCPs on P in runoff were mixed, with significant declines in dissolved $\mathrm{P}$ observed during the first year of the study but not in total $\mathrm{P}$ (Table 2). All CCPs were effective in reducing dissolved $\mathrm{P}$ concentrations $\left(\mathrm{mg} \mathrm{L}^{-1}\right)$ in runoff in 2000 , with maximum declines ranging from $32-55 \%$ of dissolved $\mathrm{P}$ in runoff from the control plots. These proportional declines in runoff dissolved $\mathrm{P}$ are comparable to those observed by Stout, Sharpley, and Landa (2000) for FBC and FGD applied to grassed soils in the Ridge and Valley regions of Pennsylvania. In the current study, differences in runoff dissolved P concentrations in 2000 were clearly affected by CCP application rate. For instance, dissolved P concentrations in runoff were lowest from plots amended with FBC at $40 \mathrm{~g} \mathrm{~kg}^{-1}$, whereas dissolved $\mathrm{P}$ in runoff from plots receiving ARA at $10 \mathrm{~g} \mathrm{~kg}^{-1}$ did not differ significantly from the control. In terms of efficacy, both FBC and FGD achieved significant reductions in runoff $\mathrm{P}$ concentrations when applied at only $10 \mathrm{~g} \mathrm{~kg}^{-1}$. Trends in dissolved $\mathrm{P}$ losses $\left(\mathrm{kg} \mathrm{ha}^{-1}\right)$ were generally comparable to those observed in dissolved $\mathrm{P}$ concentrations, as flow was similar from most plots. In 2000, flow from only one treatment (FGD applied at $40 \mathrm{~g} \mathrm{~kg}^{-1}$ ) differed significantly from the control. The decreased runoff from this treatment, compounded with lower dissolved $\mathrm{P}$ concentration, resulted in a dissolved $\mathrm{P}$ loss that was only $44 \%$ of the control (Table 2 ).

The influence of CCPs on runoff dissolved $\mathrm{P}$ was short-lived, and significant differences were observed only in years 1 and 2. More important, no significant differences in runoff total $\mathrm{P}$ were observed between treatments for any of the 3 years of the study (Table 2). It is likely that particulate $\mathrm{P}$, not dissolved $\mathrm{P}$, was the dominant form of $\mathrm{P}$ in runoff. For instance, in 2000, dissolved P averaged only $9 \%$ to $23 \%$ of total P. Although particulate $\mathrm{P}$ in runoff was not directly measured, the difference between dissolved $\mathrm{P}$ and total $\mathrm{P}$ in runoff should primarily reflect particulate sources of runoff $\mathrm{P}$. Thus, from $73 \%$ to $91 \%$ of total $\mathrm{P}$ in runoff was potentially associated with eroded sediments in 2000 . The importance of particulate $\mathrm{P}$ to total $\mathrm{P}$ in runoff is supported by runoff total solids data. Estimated erosion rates averaged 1.20 and $0.98 \mathrm{Mg} \mathrm{ha}^{-1}$ in 2001 and 2002, respectively. However, there were no significant differences in erosion. Although the total solid content of runoff was not measured in 2000, there is reason to believe that erosion would have been greater in 2000 than in 2001 and 2002 as soils were freshly cultivated in 2000 to incorporate CCPs. Indeed, total P in runoff was greatest in 2000, consistent with greater erosion that year (Table 2). Undoubtedly, eroded solids included the applied CCPs as well as soil. Thus, erosion may have depleted CCPs from the soil surface, shortening the period during which they affected dissolved $\mathrm{P}$ in runoff. It is important to note that the rates of erosion observed in the current study, although substantial, were not uncharacteristic for coastal plain soils in the region. Elsewhere, Inamdar et al. (2001) reported annual erosion rates of only $0.9-1.1 \mathrm{Mg} \mathrm{ha}^{-1}$ from a row-cropped watershed on the coastal plain of Virginia.

Soil. Trends in soil properties point to a more persistent influence of CCPs on soil P solubility than was observed in runoff. Addition of CCPs to soil significantly decreased WEP of the upper $15 \mathrm{~cm}$ of soil relative to the unamended control (Table 3). Averaged across the 3 years of study, mean soil WEP followed the trend of the control $\left(18.4 \mathrm{mg} \mathrm{kg}^{-1}\right)>$ ARA $\left(17.2 \mathrm{mg} \mathrm{kg}^{-1}\right)=\operatorname{FBC}\left(16.3 \mathrm{mg} \mathrm{kg}^{-1}\right)>$ FGD $\left(13.4 \mathrm{mg} \mathrm{kg}^{-1}\right)$.

As with runoff, the effects of CCPs on WEP were transient, but in the case of FGD and FBC, the effects persisted longer than the 1-year time frame observed in the runoff study at the greater rates of application (Table 3). Specifically, incorporation of FGD significantly lowered soil WEP in October 2000, 7 months after application. Differences in soil WEP between FGD treatments and the control persisted into 2002, but diminished with time. No significant difference in soil WEP was observed between the control and FGD applied at 


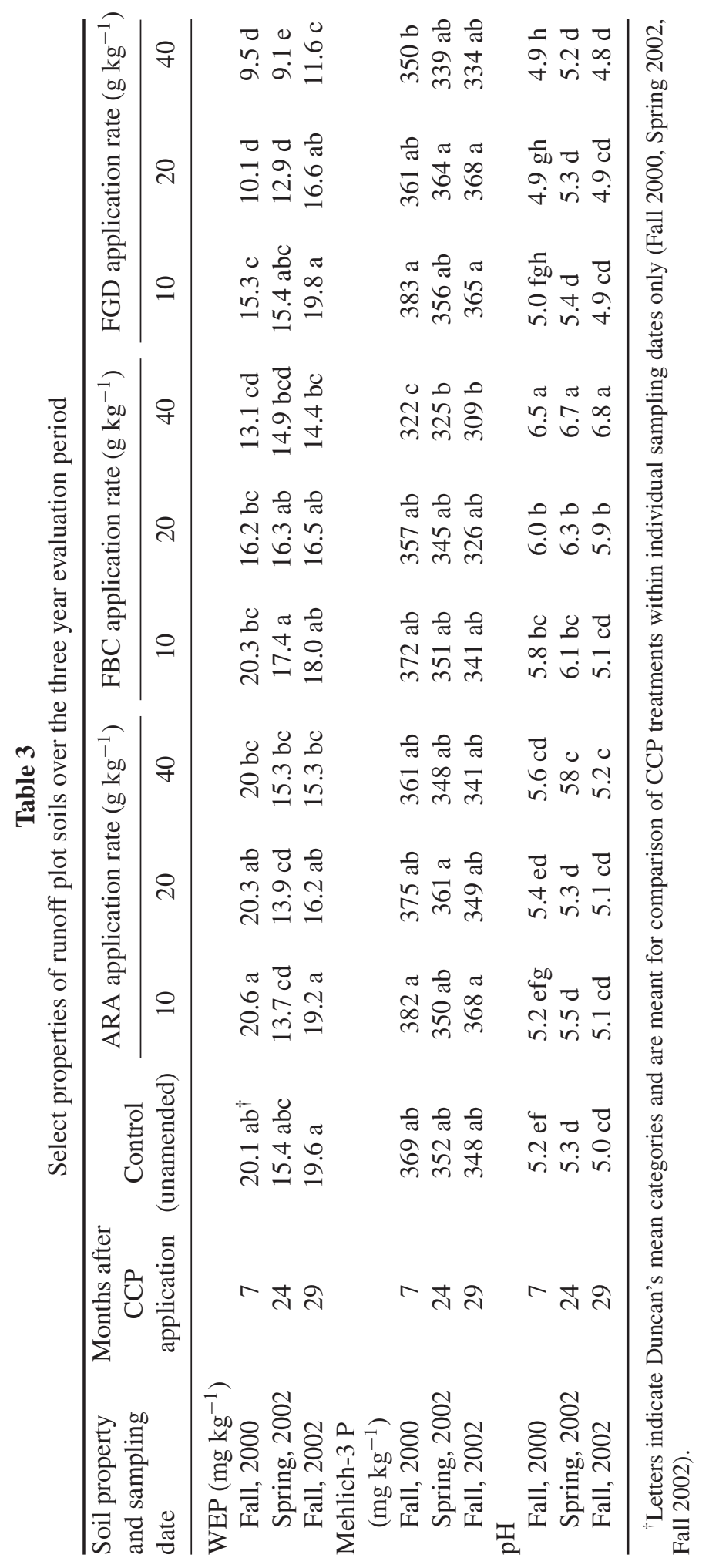


$10 \mathrm{~g} \mathrm{~kg}^{-1}$ application rate by April 2002, and only the $40 \mathrm{~g} \mathrm{~kg}^{-1}$ FGD treatment continued to differ from the control by the end of the study. In the case of FBC, significant differences in WEP were only observed at the $40 \mathrm{~g} \mathrm{~kg}^{-1}$ rate, but these differences persisted across the entire study period. However, for ARA soil WEP was significantly less than the control in October 2000 and September 2002 at the $40 \mathrm{~g} \mathrm{~kg}^{-1}$ rate.

The persistent influence of FGD and FBC on soil WEP in the 15-cm-deep samples over the 3-year study contrasted with the 1-year period during which the CCPs appeared to affect dissolved P in runoff. Differences in WEP and runoff dissolved-P trends likely represent discrepancies in the effective depth of interaction between runoff water $(<5 \mathrm{~cm})$ and the soil-sampling depth $(15 \mathrm{~cm})$. Sharpley (1985) concluded that the upper 0.1 to 3.7 $\mathrm{cm}$ of soil served as the source of dissolved P to runoff. Both CCP mixing depths and soilsampling depths were deeper than the effective depth of interaction of the plot soils. Thus, changes in soil properties within the effective depth of interaction, such as those caused by erosion of CCPs from the soil surface, may not have been detected in the 15 -cm-deep samples obtained in this study and regularly used for agronomic interpretation.

Trends in soil $\mathrm{pH}$ shed some light on differences in WEP observed among CCPs. For FGD, which had the greatest and longest-lasting effects on WEP, average soil $\mathrm{pH}$ was either significantly lower or not significantly different from the control (Table 3). Stout, Sharpley, and Pionke (1998) and Stout, Sharpley, and Landa (2000) found that the addition of FGD to soil significantly lowered $\mathrm{pH}$, while Callahan et al. (2002) found FGD to reduce $\mathrm{pH}$ in only one of four acidic soils. At a low soil pH, such as that found in this study, the displacement of $\mathrm{Al}$ and $\mathrm{Fe}$ from cation-exchange sites and ensuing formation of insoluble $\mathrm{Al}$ and Fe phosphates would likely be the major mechanism by which FGD lowered soil WEP concentration. In addition, acidification may have increased the anion exchange capacity, hence P-sorption capacity, of amphoteric minerals in the soil (McBride 1994). In contrast with FGD, application of FBC significantly increased soil pH (Table 3). Similarly to FBC, ARA also increased soil pH, but only in October 2000 and in April 2002 at the greatest application rates. At the high $\mathrm{pH}$ values induced by amending soils with $\mathrm{FBC}$, and to a lesser extent, ARA, Ca-phosphate formation likely played a role in decreasing WEP.

\section{Conclusions}

Results of this study indicate a limited, temporary impact of CCPs on dissolved P runoff from soils under continual corn production. Two CCPs, FBC and FGD, proved effective in decreasing WEP in soils to which they were applied, with effects persisting from 1-3 years, depending upon rate of application. All CCPs significantly lowered concentrations of dissolved $\mathrm{P}$ in runoff during the first year of the study, with FBC and FGD being the most effective. However, total P losses were unaffected by CCP application, probably because particulate $\mathrm{P}$ in runoff was the dominant form of $\mathrm{P}$ in runoff (dissolved $\mathrm{P}$ accounted for only $9-23 \%$ of total $P$ in runoff in the first year of the study). Perhaps because of erosion of CCPs from the soil surface, the effect of CCPs on dissolved P in runoff did not persist beyond the first year. Although erosion rates at the site were substantial (0.63-1.47 Mg $\mathrm{ha}^{-1}$ ), they were not uncharacteristically high for the area. Clearly, to be effective, CCPs must be used in a context where dissolved $\mathrm{P}$ constitutes the primary form of $\mathrm{P}$ in runoff and where erosion is minimized.

\section{Acknowledgments}

The authors are grateful to the staff of the University of Maryland Eastern Shore Nutrient Management Laboratory and USDA-ARS Pasture Systems and Watershed Management 
Laboratory for their contributions to the study. Don Mahan oversaw field work at UMES. Jaime Davis, Mary Kay Krazinski, and Joan Weaver oversaw laboratory analyses at ARS.

\section{References}

Adriano, D. M, A. L. Page, A. A. Elseewi, A. C. Chang, and I. Straughn. 1980. Utilization and disposal of fly ash and other coal residues in terrestrial ecosystems: A review. Journal of Environmental Quality 9:333-344.

Boesch, D. J., R. B. Brinsfield, and R. E. Magnien. 2001. Chesapeake Bay eutrophication: Scientific understanding, ecosystem restoration, and challenges for agriculture. Journal of Environmental Quality 30:303-320.

Brady, N. C., and R. R. Weil. 1996. The nature and properties of soils, 11 th ed. Upper Saddle River, N.J.: Prentice-Hall, Inc.

Bremner, J. M. 1996. Nitrogen-Total. In Methods of soil analysis, part 3: Chemical methods, D. L. Sparks, 1085-1121. Madison, Wisc.: Soil Science Society of America and American Society of Agronomy.

Callahan, M. P., P. J. Kleinman, A. N. Sharpley, and W. L. Stout. 2002. Assessing the efficacy of alternative phosphorus sorbing soil amendments. Soil Science 167:539-547.

Carlson, C. L., and D. C. Adriano. 1993. Environmental impacts of coal combustion residues. Journal of Environmental Quality 22:227-247.

Carpenter, S. R., N. F. Caraco, D. L. Correll, R. W. Howarth, A. N. Sharpley, and V. H. Smith. 1998. Nonpoint pollution of surface waters with phosphorus and nitrogen. Ecological Applications 8:559-568.

Chang, A. C., A. L. Page, L. J. Lund, J. E. Warneke, and C. O. Nelson. 1977. Physical properties of fly ash-amended soils. Journal of Environmental Quality 6:267-270.

Codling, E. E., R. L. Chaney, and C. L. Mulichi. 2000. Use of aluminum and iron rich residue to immobilize phosphorus in poultry litter and litter amended soils. Soil Science Society of America Journal 44:1267-1271.

Crews, J. T., and W. A. Dick. 1998. Liming acid forest soils with flue gas desulfurization by-product: Growth of northern red oak and leachate water quality. Enivronmental Pollution 103:55-61.

Ebeling, A. M., L. G. Bundy, J. M. Powell, and T. W. Andraski. 2002. Dairy diet phosphorus effects on phosphorus losses in runoff from land-applied manure. Soil Science Society of America Journal 66:284-291.

Ghodrati, M., J. T. Sims, and B. L. Vasilas. 1995. Evaluation of fly ash as a soil amendment for the Atlantic coastal plain, I: Soil hydraulic properties and elemental leaching. Water, Air, Soil Pollution 81:349-361.

Graetz, D. A., and V. D. Nair. 1995. Fate of phosphorus in Florida Spodosols contaminated with cattle manure. Ecological Engineering 5:163-181.

Inamdar, S. P., S. Mostaghimi, P. W. McClellan, and K. M. Brannan. 2001. BMP impacts on sediment and nutrient yields from an agricultural watershed in the coast plain region. Transactions of the ASAE 44:1191-1200.

Kleinman, P. J. A., A. L. Allen, B. A. Needelman, A. N. Sharpley, P. A. Vadas, L. S. Saporito, G. J. Folmar, and R. B. Bryant. 2007. Dynamics of phosphorus transfers from heavily manured coastal plain soils to drainage ditches. Journal of Soil and Water Conservation 62:225-235.

Korcak, R. F. 1995. Utilization of coal combustion by-products in agriculture and horticulture. In Agriculture Utilization of Urban and Industrial By-Products, ed. D. L. Karlen, R. J. Wright, and W. O. Kember, 107-130. Madison, Wisc.: ASA.

Kost, D. A., J. M. Bigham, R. C. Stehouwer, J. H. Beeghly, R. Fowler, S. J. Traina, W. E. Wolfe, and W. A. Dick. 2005. Chemical and physical properties of dry flue gas desulfurization products. Journal of Environmental Quality 34:676-686.

Kukier, U., M. E. Sumner, and W. P. Miller. 2001. Distribution of exchangeable cations and trace elements in the profiles of soils amended with coal combustion by-products. Soil Science 166:585-597.

Lindsay, W. L. 1979. Chemical equilibria in soils. New York: Wiley-Interscience. 
Maryland Department of the Environment. 2009. Facts about coal combustion by-products. Available at http://www.mde.state.md.us/assets/document/CCBs_Fact_Sheet.pdf.

Matsi, T., and V. Z. Keramidas. 2001. Alkaline fly ash effects on boron sorption and desorption in soils. Soil Science Society of America Journal 65:1101-1108.

McBride, M. 1994. Environmental chemistry of soils. New York: Oxford University Press.

Mehlich, A. 1984. Mehlich 3 soil test extractant: A modification of Mehlich 2 extractant. Communications in Soil Science and Plant Analysis 15:1409-1416.

Moore Jr., P. A., T. C. Daniel, and D. R. Edwards. 2000. Reducing phosphorus runoff and inhibiting ammonia loss from poultry manure with aluminum sulfate. Journal of Environmental Quality 29:37-49.

Murphy, J., and J. P. Riley. 1962. A modified single solution method for the determination of phosphate in natural waters. Analytica Chimica Acta 27:31-36.

Novak, J. M., and D. W. Watts. 2005. An alum-based water treatment residual can reduce extractable phosphorus concentrations in three phosphorus-enriched coastal plain soils. Journal of Environmental Quality 34:1820-1827.

O'Reilly, S. E., and J. T. Sims. 1995. Phosphorus adsorption and desorption in a sandy soil amended with high rates of coal fly ash. Communications in Soil Science and Plant Analysis 26:29832993.

Page, A. L., A. A. Elseewi, and I. Straughan. 1979. Physical and chemical properties of fly ash from coal-fired power plants with reference to environmental impacts. Residue Reviews 71: $83-120$.

Peters, J. M., and N. T. Basta. 1996. Reduction of excess bioavailable phosphorus in soils using municipal and industrial wastes. Journal of Environmental Quality 25:1235-1241.

Pote, D. H., T. C. Daniel, D. J. Nichols, A. N. Sharpley, P. A. M. Jr., D. M. Miller, and D. R. Edwards. 1999. Relationship between phosphorus levels in three Ultisols and phosphorus concentrations in runoff. Journal of Environmental Quality 28:170-175.

Punshon, T., D. C. Adriano, and J. T. Weber. 2001. Effect of flue gas desulfurization residue on plant establishment and soil and leachate quality. Journal of Environmental Quality 30:1071-1080.

SAS Institute Inc. 1999. SAS Online Doc, ver. 8. Cary, N.C.: SAS.

Sell, N., T. McIntosh, C. Severance, and A. Peterson. 1989. The agronomic land spreading of coal bottom ash: Using a regulated solid waste as a resource. Resources, Conservation and Recycling 2:119-129.

Sharpley, A. N. 1985. Depth of surface soil-runoff interaction as affected by rainfall, soil slope, and management. Soil Science Society of America Journal 49:1010-1015.

Sharpley, A. N. 2003. Soil mixing to decrease surface stratification of phosphorus in manured soils. Journal of Environmental Quality 32:1375-1384.

Sims, J. T., B. L. Vasilas, and M. Ghodrati. 1995. Evaluation of fly ash as a soil amendment for the Atlantic Coastal Plain, II: Soil chemical properties and crop growth. Water Air Soil Pollution 81:363-372.

Sims, J. T., and P. J. A. Kleinman. 2005. Managing agricultural phosphorus for environmental protection. In Phosphorus, agriculture, and the environment, ed. J. T. Sims and A. N. Sharpley, 1021-1068. Madison, Wisc.: SSA.

Smith, D. R., P. A. Moore Jr., D. M. Miles, B. E. Haggard, and T. C. Daniel. 2004. Decreasing phosphorus runoff losses from land-applied poultry litter with dietary modifications and alum addition. Journal of Environmental Quality 33:2210-2216.

Stout, W. L., and W. E. Priddy. 1996. Use of flue gas desulfurization (FGD) by-product gypsum on alfalfa. Communications in Soil Science and Plant Analysis 27:2419-2432.

Stout, W. L., A. N. Sharpley, and H. B. Pionke. 1998. Reducing soil phosphorus solubility with coal combustion by-products. Journal of Environmental Quality 27:111-118.

Stout, W. L., A. N. Sharpley, and J. Landa. 2000. Effectiveness of coal combustion by-products in controlling phosphorus export from soils. Journal of Environmental Quality 29:1239-1244.

U.S. Environmental Protection Agency. 1986. Test methods for evaluating solid waste (PB 88239223). Washington, D.C.: U.S. Government Printing Office. 